FACTA UNIVERSITATIS

Series: Physical Education and Sport, Vol. 18, No 3, 2020, pp. 621 - 634

https://doi.org/10.22190/FUPES200609060S

Research article

\title{
PHYSICAL EDUCATION AND MUSIC EDUCATION IN THE CONTEXT OF THE POSSIBILITY OF USING THE INTEGRATED LEARNING APPROACH AS A REFLECTION OF MODERN SOCIETY
}

\author{
UDC 796.371.212(532)
}

\section{Aleksandar Stojadinović, Danijela Zdravković, Vesna Zdravković}

\author{
Pedagogical Faculty, University of Niš, Vranje, Serbia
}

\begin{abstract}
The goal of this paper is to find and examine an effective methodological model that would enable students to adopt the learning content of children's folk dances accompanied by singing more successfully, and to develop a better sense of coordination, through the integration of Physical Education and Music Education. An experimental method with two parallel groups (EG - experimental and CG - control group) was applied. The experimental program was based on the recommended learning topics including children's folk dances accompanied by singing for the subjects Music Education and Physical Education. The integrated approach was applied with the students from the EG in learning about children's folk dances accompanied by singing, while the traditional learning approach was used with the students from the CG (they did not learn about the children's folk dances accompanied by singing through the integrated learning approach). In this research, a testing technique was applied with the students from both the EG and CG in order to check the level of coordination, and the instruments used were the Coordination Ability Assessment. The results obtained indicate that the students from the EG showed better coordination skills compared to the students who were not included in the experimental program. It is important to emphasize that the results obtained proved the connection between physical abilities and movement techniques in children's folk dances accompanied by singing, which supports the need to start with coordination practice as early as possible in primary school, which will bring good results in individuals' life later on.
\end{abstract}

Key words: Physical Education, Integrated Learning, Learning Topics, Music Education, Modern Society.

Received June 09, 2020 / Accepted December 11, 2020

Corresponding author: Aleksandar Stojadinović

Pedagogical Faculty, University of Niš, St. Partizanska 14, 17500 Vranje, Serbia

Phone: +381 17431960 •E-mail: stojadinovicaleksandar@gmail.com

두 2020 by University of Niš, Serbia | Creative Commons License: CC BY-NC-ND 


\section{INTRODUCTION}

A scientific analysis of the education process under the conditions of modern society and contradictory globalization is not an easy job at all. That general knowledge, or the reflection on the consequences of the second wave of modernization, as well as the modernization of the education process, is as complex and subject to accelerating change as Serbian society itself. There is a danger that the empirical studies and recent theoretical considerations from the second decade of the third millennium will be overcome very soon due to the pace of change taking place in modern society. On the other hand, it is very difficult to draw the line and interpret the importance of social changes that the school is ready to embrace through the process of education and thus integrate young generations into the global social, cultural, political and economic subsystems (Jovanović \& Zdravković, 2017). The latest trends in modern education show that there is an increasing aspiration to acquire interdisciplinary knowledge which, among other things, relies on integrated and synthetic approaches, which proves that education is adopting the social implications of the fourth industrial revolution. Modern society strives to integrate knowledge by using the interdisciplinary relations, which should allow for a worldview that focuses both on integrity and ambiguity. Such education stimulates the growth of creative potential in students. The role of integrated learning in these processes is very important, because its successful implementation will be more feasible if the course materials are freed from excessive subject differentiation, and if the integration of knowledge is embraced.

Integrated learning is an innovated model which interconnects learning topics from two or more subjects, in order to provide an adequate response to the reflections of the modern age. This teaching model erases the boundaries between different subjects. This is particularly true for the modern teaching of Music Education and Physical Education, whose curricula include similar learning topics. Therefore, new, modern types of learning need to be provided, and integrated learning is one of them. With the integrated connection of similar learning topics from the Music Education and Physical Education course, a large number of learning objectives can be achieved.

Relevant methodological references (Mejovšek, 1961; Đorđević, 1971; Stojanović, 1996; Bratić \& Filipović, 2001; Kragujević, 2005; Momčilović \& Momčilović, 2013; Jeremić \& Stanković, 2019) indicate that there is the possibility of connecting and linking the learning topics of the Music Education and Physical Education courses, with regards to children's folk dances accompanied by singing. Since this issue has so far been studied only from the perspective of each subject separately, there are no scientific facts about the effect of the integrated learning approach on the development of coordination skills in younger school-age students. The main motive that initiated the empirical research in this paper was the fact that there is not enough focus in the domestic literature on children's folk dances accompanied by singing, and the fact that there are numerous possibilities to use this learning topic in Music Education and Physical Education lessons, and that the curriculum includes certain learning objectives which relate precisely to the issue in question.

The inconsistency between the Music Education curriculum which includes the learning topics of music performing, singing and music games, and Physical Education curriculum that includes rhythmic exercises and folk dances, results in the fact that children find it difficult to adopt these learning topics if they are presented within each course, separately, and not by using the integrated learning approach. These facts justify 
our efforts to examine the integrated interdependence of children's folk dances accompanied by singing and their impact on the development of coordination at a younger school age.

This research is important because it attempts to find an efficient methodological model that would enable students to adopt the learning content of children's folk dances accompanied by singing more successfully, and to develop a better sense of coordination through the integration of physical and music education. When we talk about the development of coordination in students, it is important to take into account the sensitive phases of development, since the younger primary school age is the period when children's development can be influenced the most, which indicates when to start with the targeted development of this ability (Lazarević, Milosavljević, Lazarević, Marković \& Savić, 2018).

As our field of interest in this study is focused on the development of coordination at a younger school age, we use children's folk dances accompanied by singing and their impact on the development of coordination at a younger school age, and by reviewing the available references (Jocić, 1991; Kostić, 1994; Vlašić, Oreb, \& Furjan-Mandić, 2007; Oreb, Vlašić, \& Zagorac, 2011) it can be concluded that there has been no research that approaches this topic from an integrated learning aspect. This research is justified by the fact that the studies conducted so far have mainly focused on the connection between folk dances and primary motor skills. None of these papers dealt with children's folk dances accompanied by singing and their effect on the development of coordination at a younger school age.

The goal of this paper is to find and examine an effective methodological model that would enable students to adopt the learning content of children's folk dances accompanied by singing more successfully, and to develop a better sense of coordination, through the integration of Physical and Music Education.

\section{METHODS}

For the purposes of this paper, an experimental method with two parallel groups (experimental group-EG and control group-CG) was applied. The experimental program was based on the recommended learning topics including children's folk dances accompanied by singing for the subjects Music Education and Physical Education, according to the Rulebook on the curriculum for the first and second grade of primary education (2004), as well as the current Rulebook on the curriculum for second grade of primary education (2018). Ten learning topics were taught, once a week: Kolariću, Paniću [Cat's cradle]; Hajd na levo [Hop to the left]; Poslala me mila mati [My dear mother sent me here]; Ja posejah lubenice [I planted the watermelons]; Dunje ranke [Fresh Quince]; Mitku noge zaboleše [Mitka's Legs Hurt]; Lepa Anka [Pretty Anka]; Igra kolo u pedeset i dva [Cirle folk dance]; Prolećno kolo [Spring circle dance]; Mi smo deca vesela [We are happy children]. The integrated approach was applied with the students from the EG in learning about children's folk dances accompanied by singing, while the traditional learning approach was used with the students from the CG, which means that they did not have the opportunity to learn about the children's folk dances accompanied by singing through the integrated learning approach. In this research, a testing technique was applied with the students from both the EG and CG in order to check their level of coordination, and the instruments used were the Coordination Ability Assessment, which consisted of the following tests: the obstacle course backwards, three-ball slalom, non-rhythmic hand tapping, and hand and foot tapping. The selection of coordination tests for the younger school-age students is a big issue because there is 
relatively little research that tried to identify the metric characteristics on a sample of tests used in testing students of that particular age. Therefore, the coordination tests we chose for this study have a good validity that has already been proven in several larger studies (Gredelj, Metikoš, Hosek, \& Momirović, 1975; Kurelić et al., 1975; Metikoš, Gredelj, \& Momirović, 1979; Metikoš, Prot, Hofman, Pintar, \& Oreb, 1989; Bala, 1981, 1999, 2007). The instruments were taken from a battery of tests for the assessment of coordination, which was first used in the research conducted by Gredelj and associates in 1975. For the purposes of the research conducted by Kostić (1986), the instruments Obstacle course backwards and Three-ball slalom were slightly modified and thus adjusted to the younger school age students - participants in the study. The Obstacle course backwards test was modified so that the track was shortened from 10 meters to 6 meters, while in the Three-ball slalom test, the track was shortened from 10 meters to 8 meters. These modified tests are suitable for the age of the participants in our research, and we will use them as such.

Coordination tests were performed in the gymnasium in conditions of good lighting and temperature. During the coordination test, the students wore sports equipment, intended for physical education classes. Before the measurement was started, the examiners (physical education teacher and authors of this research) demonstrated to the participants how to perform the test several times. After the demonstration of the test by the examiners, each student was assessed separately.

There was a separate measurement sheet for each student, where the results of the coordination assessment were entered.

We used Cronbach's alpha coefficient of reliability to calculate the reliability of the coordination tests used on students attending the second grade of primary school. All the subscale values of the Coordination Assessment have Cronbach's alpha coefficient values above 0.700 , which means that they are reliable and range from 0.756 to 0.903 .

At the very beginning of the research, the students did an initial test (the initial and final tests were identical) whose purpose was to provide insight into the starting coordination skills in students in both the EG and CG.

After the experimental program was completed with the students of the EG and CG, the final test was given to them (the initial and final tests were identical), the purpose of which was to determine:

(1) whether and to what extent the students from the EG progressed in terms of the development of coordination compared to the initial test they took?

(2) whether there is a difference in the results achieved between the students from the EG and CG after the implementation of the experimental program?

As coordination skills are not innate, but are developed through learning (Malacko, Stanković, Doder, \& Pejčić, 2015), the studies related to the training of children and youth (Weineck, 1996 according to Crnokić, 2010) the focus is on the development of coordination skills in children aged between 7 and 12. This particular data affected our choice of the age of our study participants, which was between 8 and 9 years of age, that is, second graders. The research sample was selected from the students who attended the second grade of primary school in the city of Vranje in $2015 / 2016$. The total number of students who participated in the research was 173. It should be emphasized that in each phase of the research a certain number of students were absent from school and that these students could not be tested additionally, which is why the final sample included only those students who were in class on the days when both initial and final testing were carried out. Therefore, the valid sample consists of 162 students. The EG consisted of 80 students from four classes of 
the primary school "Jovan Jovanović Zmaj" from Vranje. The CG of students consisted of 82 students from four classes of the primary school "Vuk Karadzić" in Vranje.

Data analysis showed that the EG and the CG were identical from the aspect of the sample structure $\left(\chi^{2}=0.025, \mathrm{df}=1, \mathrm{p}=0.875\right)$. Moreover, $49.38 \%$ of the study participants were in the EG, while $50.62 \%$ of the participants were in the CG.

Statistical analysis of data was performed by using the computer program SPSS ver. 21 (Statistical Package for the Social Sciences). The level of statistical significance was defined at the level of probability from $p \leq 0.05$ to $p<0.01$. The following statistical tools were used for data analysis:

- Identifying descriptive characteristics: mean value $(M)$ and standard deviation $(S D)$, maximum and minimum;

- The differences between the groups were determined using the Analysis of variance (ANOVA);

- Repeated Measures Analysis of Variance was used to examine the differences between two measurements on the same subjects;

- Analysis of covariance (ANCOVA) was used to examine the difference between the EG and CG, with the effect of the initial measurement removed.

\section{RESULTS}

\section{Comparative results of the initial measurement of the level of coordination skills in the EG and CG}

Before the implementation of the experimental program, the test for the assessment of coordination in students attending the second grade of primary school determined the initial level of their coordination skills. The results obtained are shown in Table 1.

Table 1 Results of measuring the initial state of coordination in the EG and CG

\begin{tabular}{|c|c|c|c|c|c|c|}
\hline & Group & $\mathrm{N}$ & $\bar{M}$ & SD & $\mathrm{F}$ & $\mathrm{p}$ \\
\hline \multirow{2}{*}{$\begin{array}{l}\text { Obstacle course } \\
\text { backwards }\end{array}$} & EG & 80 & 16.9515 & 4.92581 & \multirow{2}{*}{-.160} & \multirow{2}{*}{.873} \\
\hline & $\mathrm{CG}$ & 82 & 16.8288 & 4.81431 & & \\
\hline \multirow{2}{*}{ Three-ball slalom } & $\mathrm{EG}$ & 80 & .9675 & .33427 & \multirow{2}{*}{-.183} & \multirow{2}{*}{.855} \\
\hline & $\mathrm{CG}$ & 82 & .9583 & .30704 & & \\
\hline \multirow{2}{*}{$\begin{array}{l}\text { Non-rhythmic hand } \\
\text { tapping }\end{array}$} & $\mathrm{EG}$ & 80 & 7.8625 & 2.38531 & \multirow{2}{*}{-.395} & \multirow{2}{*}{.694} \\
\hline & $\mathrm{CG}$ & 82 & 7.7195 & 2.22375 & & \\
\hline \multirow{2}{*}{ Hand and foot tapping } & EG & 80 & 6.9998 & 1.65812 & \multirow{2}{*}{.301} & \multirow{2}{*}{.764} \\
\hline & $\mathrm{CG}$ & 82 & 6.9756 & 1.53941 & & \\
\hline
\end{tabular}

Legend: N-number of participants; M-Mean (the average value of the variable in the sample); SD-Standard deviation (the average deviation of the individual variable values from the average in the sample); F-Analysis of variance (ANOVA); p-statistical significance

Comparisons were made for all four coordination tests in the EG and CG. The results have shown that there was no statistically significant difference between the EG and CG in the coordination tests. 
The average time it took the EG to complete the Obstacle course backwards test was $\mathrm{M}=16.9 \mathrm{~s}$, and for the $\mathrm{CG} \mathrm{M}=16.8 \mathrm{~s}(\mathrm{~F}=-.160, \mathrm{p}=.873)$. The average time it took the EG to take the Three-ball slalom test was $\mathrm{M}=0.96 \mathrm{~s}$, and for the $\mathrm{CG} \mathrm{M}=.95 \mathrm{~s}(\mathrm{~F}=-.183$, $\mathrm{p}=.855)$. The average number of correctly performed cycles in the Non-rhythmic hand tapping test by the EG was $\mathrm{M}=7.86$, and by the $\mathrm{CG} \mathrm{M}=7.71$ ( $\mathrm{F}=-.395 \mathrm{p}=.694)$. The average number of correctly performed cycles in the Hand and foot tapping test by the EG was $\mathrm{M}=6.90$, and by the $\mathrm{CG} \mathrm{M}=6.97(\mathrm{~F}=.301, \mathrm{p}=.764)$. The statistical significance was above the value of 0.05 , so we can conclude that the participants from the EG and $\mathrm{CG}$ had the same results on all coordination tests.

\section{Comparative results of the initial and final measurements of the level of coordination skills in the $\mathbf{C G}$}

In order to get the objective data on the level of coordination skills in the CG, we analyzed the data obtained during the initial and final testing. The results of the final testing of the level of coordination in the students from the CG shown in Table 2 indicate that certain changes are evident, but that they are not statistically significant.

Table 2 The results of the initial and final measurements of the level of coordination skills in the $\mathrm{CG}$

\begin{tabular}{|c|c|c|c|c|c|c|}
\hline Control group & & $\mathrm{N}$ & $\mathrm{M}$ & SD & $\mathrm{F}$ & $\mathrm{p}$ \\
\hline \multirow{2}{*}{ Comparison 1} & INITIAL, Obstacle course backwards & 82 & 16.8288 & 4.81431 & \multirow{2}{*}{1.027} & \multirow{2}{*}{.308} \\
\hline & FINAL, Obstacle course backwards & 82 & 16.1406 & 3.41011 & & \\
\hline \multirow{2}{*}{ Comparison 2} & INITIAL, Three-ball slalom & 82 & .9583 & .30704 & \multirow{2}{*}{3.586} & \multirow{2}{*}{.071} \\
\hline & FINAL, Three-ball slalom & 82 & .8500 & .30374 & & \\
\hline \multirow{2}{*}{ Comparison 3} & INITIAL, Non-rhythmic hand tapping & 82 & 7.7195 & 2.22375 & \multirow{2}{*}{.894} & \multirow{2}{*}{.374} \\
\hline & FINAL, Non-rhythmic hand tapping & 82 & 7.9178 & 2.14444 & & \\
\hline \multirow{2}{*}{ Comparison 4} & INITIAL, Hand and foot tapping & 82 & 6.9756 & 1.53941 & \multirow{2}{*}{-.961} & \multirow{2}{*}{.339} \\
\hline & FINAL, Hand and foot tapping & 82 & 7.1463 & 1.65643 & & \\
\hline
\end{tabular}

The results show that there is no statistically significant difference in any of the four coordinated tests.

For the Obstacle course backwards test $(\mathrm{F}=1.027, \mathrm{p}=.308)$ and the Three-ball slalom test $(\mathrm{F}=3.586, \mathrm{p}=.071)$, the time to perform the task was shorter (the average mean value proves this), while in the Non-rhythmic hand tapping test $(\mathrm{F}=.894, \mathrm{p}=.374)$ and the Hand and foot tapping test $(\mathrm{F}=.961, \mathrm{p}=.339)$ the number of correctly performed cycles increased.

\section{Comparative results of the initial and final measurements of the level of coordination skills in the EG}

Since the intention of this research was to also examine the effects of the implementation of the experimental program on the development of coordination skills in students, Table 3 shows the results of the students at the initial and final measurement as part of the coordination test. 
Table 3 The results of the initial and final measurements of the level of coordination skills in the EG

\begin{tabular}{|c|c|c|c|c|c|c|}
\hline \multicolumn{2}{|c|}{ Experimental group } & $\mathrm{N}$ & $\mathrm{M}$ & SD & $\mathrm{F}$ & $\mathrm{p}$ \\
\hline \multirow{2}{*}{ Comparison 1} & INITIAL, Obstacle course backwards & 80 & 16.9515 & 4.92581 & \multirow{2}{*}{3.039} & \multirow[t]{2}{*}{.003} \\
\hline & FINAL, Obstacle course backwards & 80 & 15.1842 & 3.01458 & & \\
\hline \multirow{2}{*}{ Comparison 2} & INITIAL, Three-ball slalom & 80 & .9675 & .33427 & \multirow{2}{*}{6.916} & \multirow[t]{2}{*}{.000} \\
\hline & FINAL, Three-ball slalom & 80 & .6513 & .29822 & & \\
\hline \multirow{2}{*}{ Comparison 3} & INITIAL, Non-rhythmic hand tapping & 80 & 7.8625 & 2.38531 & \multirow{2}{*}{-23.386} & \multirow[t]{2}{*}{.000} \\
\hline & FINAL, Non-rhythmic hand tapping & 80 & 9.3625 & 2.40907 & & \\
\hline \multirow{2}{*}{ Comparison 4} & INITIAL, Hand and foc & 80 & 6.9998 & 1.65812 & \multirow{2}{*}{-25.437} & \multirow[t]{2}{*}{.000} \\
\hline & FINAL, Hand and foot tapping & 80 & 8.6375 & 2.04533 & & \\
\hline
\end{tabular}

Based on the results obtained, we can conclude that there is a statistically significant difference between the results on the initial and the final coordination test taken by the EG. The statistical significance of this test shows that a statistically significant difference exists for all coordination tests: the Obstacle course backwards $(F=3.039, p=.003)$, Threeball slalom $(\mathrm{F}=6.916, \mathrm{p}=.000)$, Non-rhythmic hand tapping $(\mathrm{F}=-23.386, \mathrm{p}=.000)$ and Hand and foot tapping $(\mathrm{F}=-25.437, \mathrm{p}=.000)$.

Based on the mean values we can conclude that the time to perform the tasks from the Obstacle course backwards test and the Three-ball slalom test during the final testing was shorter than it was during the initial testing, while the Non-rhythmic hand tapping test and the Hand and foot tapping test also showed an increased number of correctly performed cycles. The final test results were better that the results achieved on the initial test. The data show that the impact of the experimental program had a statistically significant effect, which resulted in progress in the students' level of coordination.

\section{Comparative results of the final measurements of the level of coordination skills in the EG and CG}

We wanted to determine with the final measurements, whether or not there is a statistically significant difference in the level of coordination of students from the two examined groups at the end of the experimental program. After completing the experimental program, the students from both the EG and CG took the same test they already did in the initial testing.

Table 4 shows the results of the final measurements in the coordination test for both groups.

Table 4 The results of the final measurements of the level of coordination skills in the EG and CG

\begin{tabular}{|c|c|c|c|c|c|c|}
\hline & Group & $\mathrm{N}$ & M & SD & F & $\mathrm{p}$ \\
\hline \multirow{2}{*}{ Obstacle course backwards } & EG & 80 & 15.1842 & 3.01458 & \multirow{2}{*}{1.939} & \multirow{2}{*}{.049} \\
\hline & CG & 82 & 16.1406 & 3.41011 & & \\
\hline \multirow{2}{*}{ Three-ball slalom } & EG & 80 & .6513 & .29822 & \multirow{2}{*}{2.933} & \multirow{2}{*}{.004} \\
\hline & CG & 82 & .8500 & .30374 & & \\
\hline \multirow{2}{*}{ Non-rhythmic hand tapping } & EG & 80 & 9.3625 & 2.40907 & \multirow{2}{*}{-5.235} & \multirow[b]{2}{*}{.000} \\
\hline & CG & 82 & 7.9178 & 2.14444 & & \\
\hline \multirow{2}{*}{ Hand and foot tapping } & EG & 80 & 8.6375 & 2.04533 & \multirow{2}{*}{-5.105} & \multirow{2}{*}{.000} \\
\hline & $\mathrm{CG}$ & 82 & 7.1463 & 1.65643 & & \\
\hline
\end{tabular}


When we compare the achievements of students from the EG and the achievements of students from the $\mathrm{CG}$ on the final test aimed to assess their level of coordination skills, we can see that students from the EG achieved significantly better results than the students from the CG. The results have shown that there was a statistically significant difference between the EG and CG in favor of the EG in all four coordination tests: the Obstacle course backwards, Three-Ball Slalom, Non-rhythmic hand tapping, and Hand and foot tapping.

The average time it took the EG to complete the Obstacle course backwards test during the final measurement was $\mathrm{M}=15.2 \mathrm{~s}$, and for the $\mathrm{CG} M=16.1 \mathrm{~s}(\mathrm{~F}=1.939$, $\mathrm{p}=.049)$. It should be noted that the statistical significance for the Obstacle course backwards test results is close to the limit value of 0.05 - it is not at the limit value itself, but it is very close. Therefore, since there is a statistically significant difference, we can conclude that the EG completed this test within a shorter period of time.

The average time it took the EG to take the Three-ball slalom test was $M=0.65 \mathrm{~s}$, and the CG $\mathrm{M}=0.85 \mathrm{~s}(\mathrm{~F}=2.933$, $\mathrm{p}=.004)$. Therefore, as there is a statistically significant difference present here is well, we can conclude that the EG completed this test within a shorter period of time during the final measurement.

The average number of correctly performed cycles in the Non-rhythmic hand tapping test by the $E G$ was $M=9.36$, and by the $C G M=7.91(F=-5.235, p=.000)$. The value which is below the limit value of 0.05 indicates that there is a statistically significant difference. Based on the obtained findings, it can be concluded that the participants from the EG had more correctly performed cycles compared to the CG during the final measurement.

The average number of correctly performed cycles in the Hand and foot tapping test by the $\mathrm{EG}$ was $\mathrm{M}=8.63$, and by the $\mathrm{CG} \mathrm{M}=7.14 \quad(\mathrm{~F}=-5.105, \mathrm{p}=.000)$. The statistical significance is lower than the limit value of 0.05 , so we can conclude that the participants from the EG had more correctly performed cycles compared to the CG during this final measurement as well.

\section{Analysis of the differences between the EG and CG in the level of coordination skills with the effect of the initial measurements removed}

In order to present the obtained results as clearly as possible, we wanted to be sure that the differences between the EG and CG regarding the level of coordination skills were the result of the implemented experimental program, and not the influence of the initial differences. Let us assume that it is possible that the EG has a better performance on the initial test that assessed coordination, and therefore better final results. In that case, better achievement did not happen because of the influence of the experimental program, but because of the initially better results. In order to eliminate such doubts, we used the Analysis of covariance (ANCOVA) to mathematically remove the effect of the initial measurements (covariance). Table 5 shows the differences between the EG and CG in the level of coordination skills, with the effect of the initial measurement removed. 
Table 5 The differences between the EG and CG in the level of coordination skills, with the effect of the initial measurement removed

\begin{tabular}{lccc}
\hline & $\mathrm{F}$ & $\mathrm{p}$ & $\eta^{2}$ \\
\hline Obstacle course backwards & 3.961 & $\mathbf{. 0 5 1}$ & .052 \\
Three-ball slalom & 8.745 & $\mathbf{. 0 0 4}$ & .108 \\
Non-rhythmic hand tapping & 50.364 & $\mathbf{. 0 0 0}$ & .241 \\
Hand and foot tapping & 66.883 & $\mathbf{. 0 0 0}$ & .296 \\
\hline \multicolumn{2}{l}{ Legend: F-multivariate F value; p-the statistical significance of the univariate and multivariate F-test; }
\end{tabular}
$\eta^{2}$-Eta-squared (measure of effect size).

After the statistical elimination of the effect of the results of the test performed before the introduction of the experimental program in the EG, it was found that there was a statistically significant difference between the EG and CG in the results on all four coordination tests: the Obstacle course backwards, Three-ball slalom, Non-rhythmic hand tapping, and Hand and foot tapping. Therefore, after removing the influence of the initial test, the EG and CG had different achievements on the final test. Namely, the participants from the EG showed a higher level of coordination skills compared to the participants from the CG. What caused these differences the most, as indicated by the $\eta^{2}$ measure of effect size, were the variable Hand and foot tapping with $29 \%$, and Non-rhythmic hand tapping with $24 \%$. The variable Three-ball slalom, with approximately $11 \%$ had an average impact, and the smallest impact was expressed through the variable Obstacle course backwards, with a little more than 5\%.

Based on the results obtained, it can be concluded that we have proven the assumption that the students from the EG among which the integrated learning approach was applied would achieve a higher level of coordination skills compared to the students who were not included in the experimental program.

\section{DISCUSSION}

The main aspect of our research was related to the assessment of a basic motor skill coordination. The assessment of the level of coordination skills was performed with four tests: the Obstacle course backwards, Three-ball slalom, Non-rhythmic hand tapping, and Hand and foot tapping test. The results after the implementation of the experimental program show significantly better results for the parameters in the EG compared to the CG. The EG showed greater progress on all four coordination tests compared to the initial testing, while the CG showed some progress too, but to a lesser extent. What caused these differences the most, as indicated by the $\eta^{2}$ measure of effect size, were the variable Hand and foot tapping with $29 \%$, and Non-rhythmic hand tapping with $24 \%$. The variable Three-ball slalom, with approximately $11 \%$ had an average impact, and the smallest impact was expressed through the variable Obstacle course backwards, with a little more than $5 \%$.

It can be assumed that the changes that occurred in the EG are the result of the integrated learning approach in teaching children's folk dances accompanied by singing and a more intensive learning efforts in the EG.

Compared to the initial measurement of the $\mathrm{CG}$ of students, the results of the coordination abilities test show that there were no statistically significant changes under 
the influence of the learning topics covered in regular physical education and music education classes.

Studies conducted by various authors (Krsmanović, 2000; Zrnzević, 2007) have shown that regular physical education classes are not efficient enough and that more positive effects can be achieved with various additional learning topics regarding natural movements, dance forms and additional exercises.

Due to the proven connection between, on the one hand, the anthropological characteristics and on the other hand, the technique of movement in children's folk dances accompanied by singing, it is necessary to start with the development of coordination early in childhood, which will bring good results in individuals' life later on (Hošek, 1976; Malacko, 2002).

Based on the results obtained, it can be concluded that the students from the EG in which the integrated learning approach was applied would achieve a higher level of coordination skills compared to the students who were not included in the experimental program. Based on the results of our research, which are in line with the findings confirmed in the previous hypothesis, we emphasize that the teaching process based on the integrated learning approach and organized so that students are provided with the knowledge from the related learning topics and courses, will allow the student to achieve better results on aptitude tests than those students who learn following the traditional way of learning (Lake, 1994; Mathison \& Freeman, 1997).

\section{CONCLUSION}

It has been proven that there are music-related learning contents in the curriculum that can be taught along with the related contents from other subjects in class teaching, by using the integrated learning approach. Such contents include children's folk dances accompanied by singing, which are inextricably linked with the Physical Education course. For that reason, during the development of curricula, it would be wise to highlight such learning topics that would be adequate for the implementation of integrated teaching. In that case, the timing would have to be taken into account, because certain learning topics that are related and connected should be planned in the approximate time in order to facilitate the organization and implementation of such a teaching model for teachers. This type of teaching allows the teachers use time rationally, because they do not have to repeat certain topics several times; moreover, the students get a broader picture of the learning topics, which enables them to connect them more easily, understand more clearly and have more lasting knowledge.

It is evident that children's folk dances accompanied by singing have succumbed to the abundance of seemingly more interesting music that is spread by various media. Since the school can be a significant factor in preserving folk traditions and nurturing traditional values, the innovated teaching models, better organization of the teaching process, more adequate teaching aids, more modern sources of knowledge, and new scientific knowledge can make something old become more attractive to younger school-age students. Traditional music learning topics, such as children's folk dances accompanied by singing, should not be a problem for both teachers in the teaching process and the students in their understanding, accepting and adopting of such topics. Such learning topics should be the 
starting point in the development of elementary music and physical abilities, but also an important part of the general music and physical culture.

Since this research has proven the benefits of the application of integrated learning approach in teaching children's folk dances accompanied by singing, it is important to point out that the integration in the classroom implies not only a different way of learning, but also a different way of teaching, and from that aspect, the teacher has a crucial role and responsibility since they lead the teaching process. Therefore, the question arises as to how trained the teachers are to apply the integrated learning approach. Although the teachers often state that they do not have enough time to plan and implement integrated learning, and that the curriculum discourages this, it still seems that their didactic and methodological skills and knowledge required to implement such a model of teaching is the biggest issue. In that sense, there is a need for the continuous professional development of teachers, which can be realized through seminars that would deal with the issue of integrative teaching. Hence, there is a need for the continuous professional development of teachers, which can be achieved through seminars that would deal with the issue of integrated learning.

Teachers' teamwork is another important link with regards to planning, organizing and implementing learning topics based on the integrated learning model. In that sense, it is necessary to organize respectable and demonstration classes taught per the integrated learning model, where the teachers would acquire the necessary knowledge that would allow them to apply the integrated learning model in the classroom.

In addition to all the above, it is important to mention that based on the theoretical and empirical findings of this research, and especially on the results obtained after implementing the integrated learning model to teach children's folk dances accompanied by singing, new questions have arisen which should trigger further research in this field:

1. Identify the effect of the experimental factor on encouraging coordination development from the first to the fourth grade of primary school. Our research included second grade students. The implementation of the integrated learning model when teaching children's folk dances accompanied by singing from the first to the fourth grade would bring a better insight into the effects of the experimental factor;

2. Identify the effect of the experimental factor on other basic motor skills (strength, endurance, speed, flexibility, balance and precision).

Through related learning topics, this paper has merged two courses from our educational system and thus given guidelines on how to innovate the teaching process, that is, how to find effective methodological approaches to encourage the development of basic physical abilities in students.

The obtained findings on the effects of the applied experimental program in teaching Physical Education and Music Education at a younger school age speak in favor of the possibility to apply the integrated learning approach in the teaching process, despite certain material and organizational difficulties that our schools face.

The significance of this research is reflected in the data showing the possibilities and limitations of the implementation of the integrated learning model in the existing type of organization of teaching. From the didactic and methodological aspect, the importance of this research is reflected in the confirmation of the efficiency of application of the integrated model of teaching. Moreover, the results obtained can be used to design and review related learning topics in a more comprehensive way, unlike the traditional way of teaching, without deviating from the learning topics and teaching units which are determined by the Curriculum. From the aspect of physical and music education, the 
importance of this research is reflected in the fact that the efficiency of application of this learning model in teaching children's folk dances accompanied by singing was confirmed, and the results of this research, which had an experimental and empirical character, provided the information on developmental characteristics regarding the basic motor skills of coordination in students of the second grade of primary school. Children's folk dances accompanied by singing, as an inseparable segment of folk music, should have a more significant place, viewed from the aspect of sociology of sports, in order to significantly influence the enhancement of general knowledge and understanding of the importance of preserving traditional heritage during primary school education.

\section{REFERENCES}

Bala, G. (1981). Struktura i razvoj morfoloških i motoričkih dimenzija dece SAP Vojvodine (The Structure and Development of Morphological and Motor Dimensions of children from SAP Vojvodina), Novi Sad: OOUR Institute of Physical Education. In Serbian

Bala, G. (1999). Motor behavior evaluation of pre-school children on the basis of different result registration procedures of motor test performance. In: V. Strojnik, \& A. Ušaj (Eds.), Proceedings of the 6th Sport Kinetics Conference 1999 „, Theories oh Human Motor Performance and their Reflections in Practice“, (pp. 62-65). Ljubljana: University of Ljubljana, Faculty of Sport.

Bala, G. (2007). Morfološke karakteristike predškolske dece. In: Antropološke karakteristike $i$ sposobnosti predškolske dece (Morphological Characteristics of Preschool Children. In: Anthropological Characteristics and Abilities of Preschool Children), (pp. 31-66). Novi Sad: Faculty of Sport and Physical Education, University of Novi Sad. In Serbian

Bratić, T., \& Filipović, Lj. (2001). Muzicka kultura u razrednoj nastavi (Music Education in class teaching). Jagodina-Pristina: Faculty of Education in Jagodina, University of Kragujevac/Faculty of Arts of Priština, University of Priština. In Serbian

Crnokić, S. (2010). Opće koordinacijske vježbe u treningu djece 6-10 godina starosti. (General coordination exercises in training children from 6 to 10 years of age). Retrieved on May 14 ${ }^{\text {th }}, 2015$, from: http://skolskisport.hr/assets/files/Primjena_OKVUTD.pdf. In Croatian

Gredelj, M., Metikoš, D., Hošek, A., \& Momirović, K. (1975). Model hijerarhijske strukture motoričkih sposobnosti. Rezultati dobijeni primenom jednog neoklasičnog postupka za procjenu latentnih dimenzija (Model of hierarchical structure of motor abilities. Results obtained using a neoclassical procedure to estimate latent dimensions), Kineziologija, 5(1-2), 7-82. In Croatian

Đorđević, D. (1971). Telesno vaspitanje u drugom razredu osnovne skole, prirucnik za učitelje (Physical education in the second grade of primary school, a handbook for teachers). Belgrade: Institute for Textbook Publishing of the Socialist Republic of Serbia.

Hošek, A. (1976). Struktura koordinacije (Coordination Structure). Kineziologija, 6(1-2), 72-78. In Croatian

Jeremić, B., \& Stanković, E. (2019). Metodika nastave muzičke kulture za predškolski i mlađi školski uzrast (Methodology of Teaching Music to Preschool and Younger School Age Students). Sombor: Faculty of Education in Sombor, University of Novi Sad. In Serbian

Jocić, D. (1991). Predviđanje uspeha u plesovima na osnovu morfološkog, motoričkog, kognitivnog i konativnog statusa (Predicting success in dancing based on morphological, motor, cognitive, and conative status). Doctoral Dissertation. Belgrade: Faculty of Sport and Physical Education, University of Belgrade. In Serbian

Jovanović, M., \& Zdravković, D. (2017). Nonverbal communication and physical education classes in a social context. Facta Universitatis Series Physucal Education and Sport, 15(1), 195-206.

Kragujević, G. (2005). Teorija i metodika fizickog vaspitanja za ucitelje i studente učiteljskog fakulteta (Theory and Methodology of Physical Education for Teachers and Students at the Faculty of Education). Belgrade: Zavod za udžbenike i nastavna sredstva. In Serbian

Krsmanović, B. (2000). Metodika fizičkog vaspitanja (Methodology of Physical Education). Novi Sad: Faculty of Physical Culture, University of Novi Sad. In Serbian

Kostić, R. (1994). Predikcija izvođenja narodnih i društvenih plesova (Prediction of performing folk and social dances). Fizicka kultura, 48(4), 354-358. In Serbian

Kostić, R. (1986). Relacije između koordinacije i muzičkih sposobnosti učenika. (Relationship between coordination and students' musical abilities). Doctoral Dissertation. Niš: Faculty of Philosophy, University of Niš. In Serbian 
Kurelić, N., Momirović, K., Stojanović, M., Šturm, J., Radojević, Đ., \& Viskić-Štalec, N. (1975). Struktura $i$ razvoj morfoloških i motoričkih dimenzija omladine (Structure and Development of Morphological and Motor Dimensions of Young People), Belgrade: Institute for Scientific Research, Faculty of Physical Education in Belgrade, University of Belgrade. In Serbian

Lake, K. (1994). Integrated curriculum. School improvement research series. Portland, OR: Northwest Regional Educational Laboratory.

Lazarević, P., Milosavljević, S., Lazarević, S., Marković, V., \& Savić, A. (2018). Different levels of motor abilities in boys and girls aged 10 and 9. Facta Universitatis Series Physucal Education and Sport, 16(1), 189-199.

Malacko, J. (2002). Sportski trening (Sports training). Novi Sad: Faculty of Sport and Physical Education, University of Novi Sad. In Serbian

Malacko, J., Stanković, V., Doder, D., \& Pejčić, A. (2015). Gender differences in the morphological characteristics and motor skills of children aged 7 to 11. Facta Universitatis Series Physucal Education and Sport, 13(1), 114-125.

Mathison, S., \& Freeman, M. (1997). The logic of interdisciplinary studies. Retrieved on September 11, 2016, from the World Wide Web: http://www.albany.edu/cela/reports/mathisonlogic12004.pdf

Mejovšek, M. (1961). Fizički odgoj u osnovnoj školi (Physical Education in Primary School), Zagreb: Tipografija. In Croatian

Metikoš, D., Gredelj, M., \& Momirović, K. (1979). Struktura motoričkih sposobnosti (Structure of motor abilities), Kineziologija, 9(1-2), 25-50. In Croatian

Metikoš, D., Prot, F., Hofman, E., Pintar, Ž., \& Oreb, G. (1989). Mjerenje bazičnih motoričkih dimenzija sportaša. (Measuring the basic motor dimensions of athletes). Zagreb: Faculty of Physical Education, University of Zagreb. In Croatian

Momcilović, Z. \& Momcilović, V. (2013). Fizičko vaspitanje i sport (Physical education and sport). Vranje: Faculty of Education, University of Niš. In Serbian

Oreb, G., Vlašić, J., \& Zagorac, M. (2011). The efficiency of a dance training on some motor abilities of folk dancers. Sport Science, 4(1), 96-100.

Pravilnik o nastavnom planu i programu za prvi i drugi razred osnovnog obrazovanja $i$ vaspitanja (Rulebook on the Curriculum for the First and Second Grade of Primary School), from 21/07/2004. Belgrade. In Serbian

Pravilnik o programu nastave $i$ učenja za drugi razred osnovnog obrazovanja $i$ vaspitanja, (Rulebook on the Curriculum for the First and Second Grade of Primary School), from 27 ${ }^{\text {th }}$ August, 2018. Belgrade. In Serbian

Stojanović, G. (1996). Nastava muzicke kulture (Music education classes), Belgrade: Zavod za udžbenike i nastavna sredstva. In Serbian

Vlašić, J., Oreb, G., \& Furjan-Mandić, G. (2007). Motor and morphological characteristics of female university students and the efficiency of performing folk dances. Kinesiology, 39(1), 49-61.

Weineck, J. (1996). Training manual. Paris: Vigot Ed.

Zrnzević, N. (2007). Transformacija morfoloških karakteristika, funkcionalnih i motoričkih sposobnosti učenika (Transformation of morphological characteristics, functional and motor abilities of students). Unpublished Doctoral Dissertation, Niš: Faculty of Sport and Physical Education, University of Niš. In Serbian

\section{FIZIČKO VASPITANJE I MUZIČKA KULTURA U KONTEKSTU MOGUĆNOSTI PRIMENE INTEGRATIVNOG PRISTUPA KAO REFLEKSIJE SAVREMENOG DRUŠTVA}

Cilj ovog rada je ispitivanje efikasnog metodičkog modela koji bi omogućio da učenici, kroz integraciju fizičkog i muzičkog obrazovanja, uspešnije usvajaju nastavne sadržaje dečje narodne igre sa pevanjem, te da efikasnije razvijaju osećaj za koordinaciju, kroz integraciju Fizičkog vaspitanja i Muzičke kulture. Za potrebe ovog rada primenjena je eksperimentalna metoda sa dve paralelne grupe (EG-eksperimentalna i $K G$-kontrolna). Eksperimentalni program koncipiran je na osnovu preporučenih sadržaja dečje narodne igre sa pevanjem za predmete Muzička kultura i Fizičko vaspitanje. Sa učenicima EG primenjen je integrativni pristup u obradi sadržaja dečje narodne igre sa pevanjem, a sa učenicima $K G$ nastava je realizovana na klasičan način (oni nisu imali priliku da integrativnim modelom učenja usvoje nastavne sadržaje dečje narodne igre sa pevanjem). U ovom istraživanju primenjena je tehnika testiranja koja je izvršena sa učenicima EG $i$ $K G$ u cilju provere nivoa razvijenosti koordinacije, a od instrumenata primenjen je Test procene 
sposobnosti koordinacije. Dobijeni rezultati ukazuju na to da učenici iz EG u kojoj je primenjen integrativni metodički pristup pokazuju viši nivo razvijenosti koordinacije u odnosu na učenike koji nisu obuhvaćeni eksperimentalnim programom. Značajno je naglasiti da su dobijeni rezultati dokazali povezanost fizičkih sposobnosti i tehnike kretanja u dečjim narodnim igrama sa pevanjem, što ukazuje na opravdanost potrebe da se što ranije u osnovnoj školi krene sa razvojem koordinacije, što će dati solidne individualne rezultate u kasnijoj životnoj dobi ispitanika.

Ključne reči: fizičko vaspitanje, integrativna nastava, nastavni sadržaji, muzička kultura, savremeno društvo. 